\title{
Zooplankton characterisation of Pampean saline shallow lakes, habitat of the Andean flamingoes
}

\author{
Yamila S. BATTAUZ, ${ }^{1 *}$ Susana B. JOSÉ de PAGGI, ${ }^{1,2}$ Juan C. PAGGI, ${ }^{1}$ Marcelo ROMANO, ${ }^{3}$ Ignacio BARBERIS ${ }^{4}$ \\ ${ }^{1}$ Instituto Nacional de Limnología, Consejo Nacional de Investigaciones Científicas y Técnicas y Universidad Nacional del Litoral, \\ Ciudad Universitaria - Paraje El Pozo, 3000 Santa Fe; ${ }^{2}$ Facultad de Bioquímica y Ciencias Biológicas, Universidad Nacional del \\ Litoral, Ruta Nacional 168, 3000 Santa Fe; ${ }^{3}$ Centro de Investigaciones en Biodiversidad y Ambiente (Ecosur), Pasaje Sunchales 329 , \\ 2000 Rosario; ${ }^{4}$ Consejo Nacional de Investigaciones Científicas y Técnicas y Facultad de Ciencias Agrarias, Universidad Nacional \\ de Rosario, Campo Experimental Villarino, 2125 Zavalla, Argentina \\ *Corresponding author: yamilabattauz@gmail.com
}

\begin{abstract}
The lowland saline shallow lakes in the Pampa de las Lagunas (Argentina), constitute an important habitat for flamingoes Phoenicopterus chilensis Molina and Phoenicoparrus andinus (Philippii). Little is known about the zooplankton communities of these systems, and their relationships with the temporal and spatial distribution of flamingoes. Ten shallow lakes in the Pampean region were studied in 2009 and 2010 winters, and in 2010 summer in order to assess the abundance, size and biomass of zooplankton and the density of flamingoes populations. Zooplankton was represented by 28 species. Copepods and cladocerans were dominant when salinity was lower (winter and summer of 2010). Seasonal changes were recorded in composition and mean abundance of zooplankton. Significant differences were observed in mean size of zooplankton showing a negative relationship with the abundance of $\mathrm{P}$. chilensis, which can be interpreted as a consequence of the selective flamingoes zooplanktophagy feeding upon the largest members of this community. Other community parameters, such as abundance, biomass, diversity and composition, did not show an apparent direct relationship with the presence or abundance of flamingoes.
\end{abstract}

Key words: Phoenicopterus chilensis, zooplankton richness, zooplankton size, biomass, trophic relationships.

Received: February 2013. Accepted: April 2013.

\section{INTRODUCTION}

In West Central Argentina, in Pampa de las Lagunas (southwestern Santa Fe and southern Córdoba provinces), there are several lowland saline wetlands embedded in a landscape where $70 \%$ of the area is used as grazing pastures and agricultural fields (Romano et al., 2005). Many of these shallow lakes are important habitats for two flamingoes species, the Chilean flamingo (Phoenicopterus chilensis Molina) and the Andean flamingo [Phoenicoparrus andinus (Philippii)]. The former is the most abundant species with a meridional distribution, ocurring from central Peru, through the Andes to southern Argentina, Tierra del Fuego, extending eastwards to Southern Brazil and Uruguay (Del Hoyo, 1992). As vagrant, this species has also been found in Ecuador and in the Malvinas (Falkland) islands. Despite its relative abundance and ample distribution, this species is classified as near threatened by IUCN (BirdLife International, 2008b) due to several reasons, mainly disturbance and habitat degradation.

The Andean Flamingo is a well-known inhabitant of the saline lakes in the High Andes of Argentina and Chile (Jenkin, 1957; Hurlbert and Chang, 1983) but compared to the Chilean flamingo, its presence is scarce. It is con- sidered the world's rarest species and has been qualified as Vulnerable according to IUCN criteria (BirdLife International, 2008a). These flamingo species show contrasting temporal and spatial patterns in the Pampean region. The Chilean flamingo inhabits most of these lowland wetlands throughout the year, whereas the Andean flamingo uses only some of them in winter (Caziani et al., 2007; Romano et al., 2009).

Most of these shallow lakes are mostly saline, but they differ in the level of salinity and the chemical composition of the water (Romano et al., 2008). They also show seasonal and annual variations in water salinity due to water level fluctuations associated with annual rainfall (Romano et al., 2008). Moreover, certain years report a so severe drought that some of these shallow lakes have completely dried out, and thus flamingoes have moved to larger and deeper lakes (Romano et al., 2009). Furthermore, food availability could also be affected by the abundance of fish, which at least in the High Andean lakes compete for food with the Chilean flamingo (Hurlbert et al., 1986).

Both flamingo species have specialised beaks that allow them to filter and feed on many planktonic and benthic organisms (Hurlbert, 1982). However, they show anatomical and structural differences in their beaks 
(Jenkin, 1957; Mascitti and Kravetz, 2002). Chilean flamingoes have beaks with interlamellar spaces of about $0.5 \mathrm{~mm}$, whereas Andean flamingoes have beaks with filters of intermediate-sized mesh with interlamellar spaces measuring between 0.06 and $0.14 \mathrm{~mm}$ (Jenkin, 1957). These anatomical and structural differences between flamingo species suggest that they also differ in their diet. The Chilean flamingo filter a great variety of both animal and plant material according to some food records (Jenkin, 1957; Mascitti and Kravetz, 2002), feeding mainly on crustaceans (copepods, cladocerans, ostracods). Andean flamingos mainly feed on the diatom Surirella in lakes in the Bolivian Andes (Hurlbert and Chang, 1983). There is some information about the abundance and composition of zooplankton dwelling in the High Andes salt lakes (Hurlbert and Chang, 1983), as well as information about the effects of flamingoes upon zooplankton, and their interactions wih fish in the High Andes (Hurlbert et al., 1986). However, nothing has been published about the zooplankton of the shallow saline lowland lakes of the Pampa de las Lagunas region (southwestern Santa Fe and southern Cordoba provinces) and their potential relation to the distribution of flamingoes. Therefore, to gain a better insight about the relationship between flamingoes and the functioning of these shallow lakes, the aim of this work is to study the role of the zooplankton communities as feeding sources for flamingoes taking into account that it could be a valuable tool for developing an efficient conservation policy for these waterfowls. For this purpose, we carried out three seasonal surveys of 10 shallow lakes inhabited by flamingoes in that region, our specific objetives are to assess i) the spatial and temporal variation in composition, abundance, size and biomass of zooplankton, ii) the spatial and temporal abundance patterns of the flamingoes species, and iii) whether one of these flamingoes species, or both show evidence of interaction with zooplankton.

We hypothesise, i) the predation of both flamingo species in the shallow lakes changes the structure of the zooplankton comunities; and ii) the abundance, richness and body-size spectrum, of these communities decrease as abundance of flamingoes increase.

\section{Description of the study area}

The study was conducted in 10 shallow lakes in an area located between $33^{\circ} 42^{\prime}-34^{\circ} 18^{\prime} \mathrm{S}$ and $61^{\circ} 25^{\prime}-62^{\circ} 32^{\prime}$ $\mathrm{W}$, where flamingoes were mostly continuously present during the periods studied. Lakes Las Tunas (LT), La Badenia (LB), Maggiolo (MA), La Picasa (LP), Bella Vista (BV), Martín García (MG) and Carmen (CN), are close to each other forming one group. Other more distant lakes are Melincué (ME) and Quirno (QN), constituting the second group, and between the two groups the shallow lake known as Las Encadenadas (EN) lies (Fig. 1). Most lakes of the first group have a size smaller than $20 \mathrm{~km}^{2}$, except for LP, ME and QN with a surface of 168.34, 65.77 and $40.28 \mathrm{~km}^{2}$, respectively.

Because of their shallow nature and the free exposure to winds in the Pampean lowland landscape, these lakes are polymictic with an active interaction between bottom sediments and water column. Frequently organic and inorganic sediments are resuspended so that the turbidity of the water is not a direct and unbiassed indicator of phytoplankton production.

The maximum deph of the lakes is less than $3 \mathrm{~m}$, only LP and ME have depths between 5 and $7 \mathrm{~m}$. Las Tunas and $\mathrm{ME}$ are tectonic in origin, while the remaining ones are fluvial in origin (Iriondo and Krohling, 2007). Most of these shallow lakes are located in endorheic basins, except for EN which is, in fact, a group of interconnected small lakes along an extended and narrow, northwestsoutheast-oriented depression, probably an old bed of an ancient river (Iriondo and Krohling, 2007).

\section{METHODS}

Sampling was performed in winters 2009-2010 and summer 2010. During winter 2010, due to operational problems, samples were not taken in EN, QN and LP. Samples and environmental measurements were taken from shallow water similar to those of their settlement sites (0.3-0.5 $\mathrm{m}$ deep) as close as possible to flamingoes colonies. Depending on the number and location of the flamingoes settlements, one to three sampling stations were established in each lake. When sampling stations were more than one, average results were used in data analysis. Due to the shallowness of the study sites, samplings and measurements were done by wading.

Water temperature, dissolved oxygen and $\mathrm{pH}$ were determined in situ using a multiparametric probe (Lutron YK 2001; Lutron, Coopersburg, PA, USA). Water samples for physical-chemical analysis were taken using standard procedures (APHA, 1989). In the laboratory, the analyses of turbidity, chemical demand of oxygen (COD), major anions $\left(\mathrm{SO}_{4}^{-2}, \mathrm{Cl}^{-1}\right)$, cations $\left(\mathrm{Ca}^{+2}, \mathrm{Mg}^{+2}, \mathrm{Na}^{+1}, \mathrm{~K}^{+1}\right)$ and nutrientes (nitrates and phosphates) were performed according to standard analytical procedures (APHA, 1989). The salinity of the lakes was estimated per season, using a conversion table for changing electrical conductivity into salinity, derived from the equation of Weyl (1964). The lakes under study were classified on the basis of their salinity according to Hammer (1986).

Flamingoes were counted and identified to species, using $10 \mathrm{x}$ binoculars or $15 / 45 \mathrm{x}$ spotting scopes, and manual counters (Romano et al., 2009). Measurements of environmental parameters, zooplankton samples and flamingoes census were performed simultaneously.

Quantitative zooplankton samples were taken from mid-depth using a graduated plastic vessel (4 L max vol- 
ume) in enough numbers to make a composite pool sample of 20-30 L. The composite sample was filtered through a $50 \mu \mathrm{m}$ mesh net, preserved in situ with 5-10\% of buffered formalin and stained with erythosine. The general procedure applied to the zooplankton sampling was practically the same used by Hurlbert et al. (1984, 1986) with a similar purpose and under similar environmental conditions.

Zooplankton taxa were identified to the lowest taxonomic rank possible using a Nikon microscope (Nikon, Tokyo, Japan), in a $1 \mathrm{~mL}$ Kolkwitz cell (rotifers and nauplii) and a $5 \mathrm{~mL}$ Bogorov chamber (cladocerans, copepods, including copepodits). At least 100 individuals of the dominant species were counted. Taxonomic identifications were based on Ahlstrom (1940), Koste (1978), Kořínek (1981, 2002), Bayly (1992), Korovchinsky (1992), Ciros-Pérez et al. (2001), and Alekseev (2002) among others.

The mean body size estimates, including all zooplanktonic organisms, rotifers and crustaceans, were obtained from the measurement of ten specimens randomly selected of each species in every sample. Measurements were performed under microscope using an ocular fitted with a micrometer scale. Biomass was calculated after Dumont et al. (1975).

\section{Data analysis}

A cluster analysis in the Q-mode was performed to identify similarity between lakes, based upon the Morisita index (Morisita, 1959), calculated on the abundance and composition of the zooplankton. In order to explore the existence of distinct zooplankton assemblages, we also performed an R-mode cluster analyses of the 15 major species (frequency $>20 \%$ in at least one season) according to Jaccard's similarity index and a UPGMA dendrogram constructed. For this analysis, copepod larvae, unidentified to species level, were excluded.

A Mantel test (Mantel and Valand, 1970) was used for correlation between two similar matrices. The one-way analysis of variance was used to analyse the differences of zooplankton size among sampling periods. Pearson product-moment correlation coefficient was used to analyse the relationship between variables.

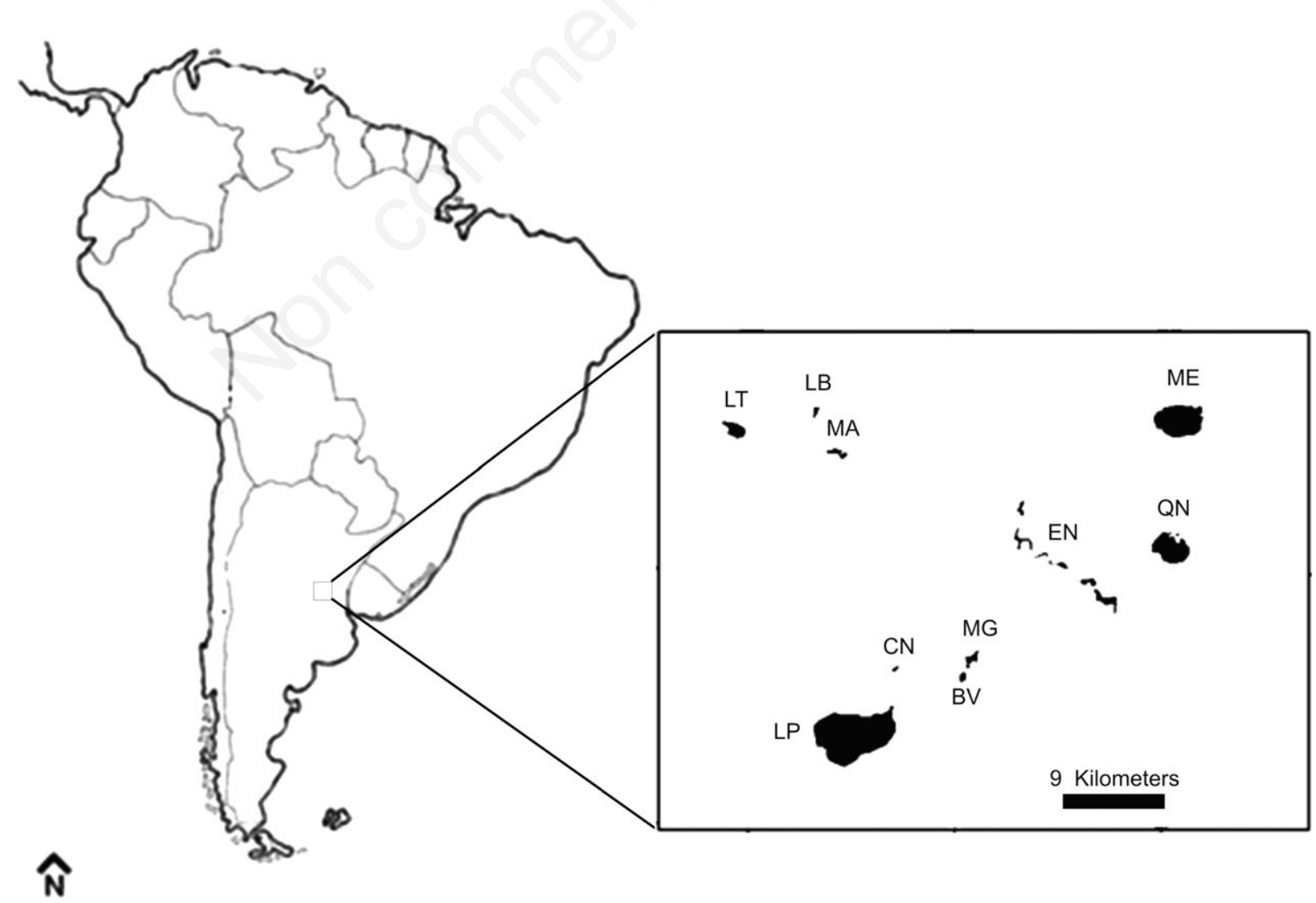

Fig. 1. Map of the studied area with locations of the lakes in the right box. 
The alpha diversity (species richness per lake, sensu Whittaker, 1972), gamma diversity (total species diversity per lake), beta diversity (as replacement of species) (Harrison et al., 1992) and specific diversity index (Shannon) were calculated. The data analyses were performed with software PAST (Hammer et al., 2001).

\section{RESULTS}

\section{Abiotic variables}

A temporal and spatial variation of the different parameters was recorded, as evidenced by the large coefficients of variation (Tab. 1).

Salinity in all the lakes under study was not constant but variable. Lakes whose salinity levels have seasonal fluctuations directly related to the pluviometric regime can be defined as poikilohaline. Depending upon the season, lakes can be referred to as hypersaline to subsaline. During winters 2009 and 2010, 15.4 and $3 \mathrm{~mm}$ of monthly rainfall were recorded, respectively. Most lakes were classified as hiposaline, mesohaline and hypersaline, while in summer 2010 with heavy pluviosity (i.e. $215.6 \mathrm{~mm}$ of monthly rainfall), most of them were subsaline or hiposaline. Mean salinities of winters were significantly lower than those of summer $(t=7.065$, $\mathrm{P}<0.0001$ ) (Tab. 2).

The ionic composition of the lakes under study shows that most of them were sodic-sulphated, [LB, BV, EN, $\left.\mathrm{ME}, \mathrm{MA}, \mathrm{MG}\left(\mathrm{Na}>\mathrm{K}>\mathrm{Ca} ; \mathrm{SO}_{4}>\mathrm{Cl}\right)\right]$, but in some of them $(\mathrm{CN}+\mathrm{BV})$ the concentration of chloride was higher. A high concentration of sulphate was recorded in LT + LB. In contrast with the rest, MA + MG showed a higher concentration of calcium and magnesium. Waters were alkaline $(\mathrm{pH}>9)$ and with high dissolved oxygen concentration. The levels of nutrients as well as phytoplankton (Melina Devercelli, unpublished data) of these lakes indicated eutrophic condition.

\section{Flamingoes}

Flamingoes were found in almost all the lakes. The cumulative number of specimens detected, in each sampling season, indicates that they were more abundant in winter 2009 (52,640 individuals) than in winter 2010 $(11,835$ individuals) or summer 2010 (13,678 individuals). The highest densities of individuals occurred in $\mathrm{ME}, \mathrm{LP}, \mathrm{CN}$ and EN, though there were also some differences in individual abundance among flamingo species over the years.

With few exceptions, Phoenicopterus chilensis was the most abundant species, representing 17 to $100 \%$ of the individuals in most lakes. Phoenicoparrus andinus, on the other hand, was normally present in a small number of individuals with the exception of ME, during winter 2009, when it reached $83 \%$ (Fig. 2).

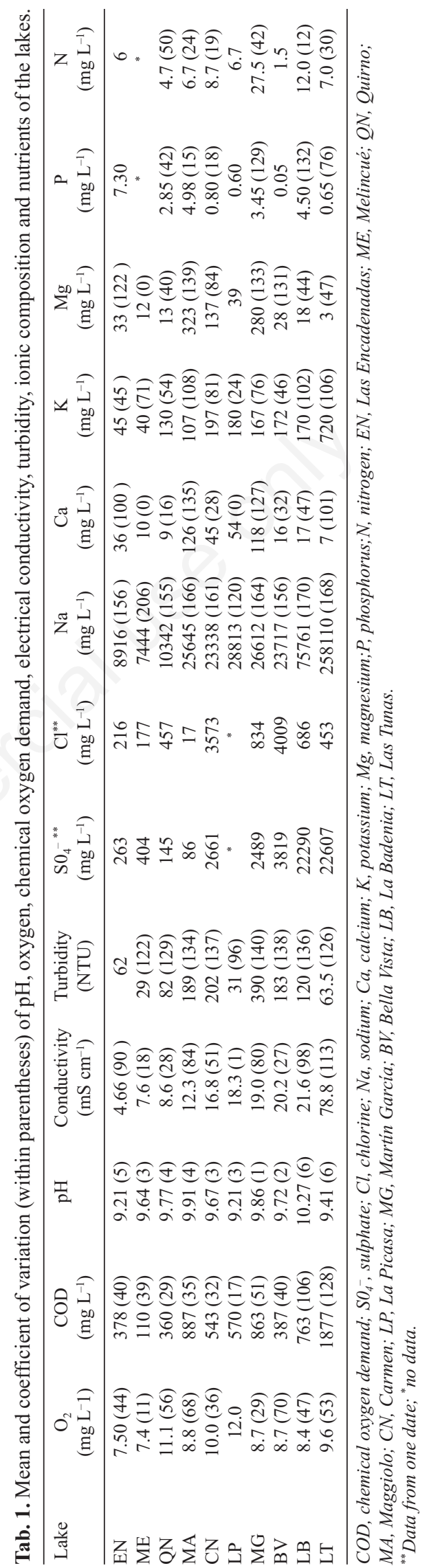




\section{Zooplankton}

\section{Composition and diversity}

Twenty-eight species make up the zooplankton communities of lakes studied (Tab. 3), with rotifers as the dominant group, most of them belonging to the genus Brachionus. Cladocerans were represented by 12 species, mainly of the genera Daphnia and Moina, and copepods were represented by 4 species of the Boeckella and Metacyclops genera. Unidentified ostracods were registered in $70 \%$ of the lakes.

Only six species, Brachionus angularis Gosse, $B$. dimidiatus Bryce, B. plicatilis Müller, Moina micrura Kurz, Metacyclops mendocinus (Wierzejski) and Boeckella poopoensis Marsh, were present in 60 to $90 \%$ of the localities. The remaining species were generally found with lower frequency.

There was not a significant correlation between simi-

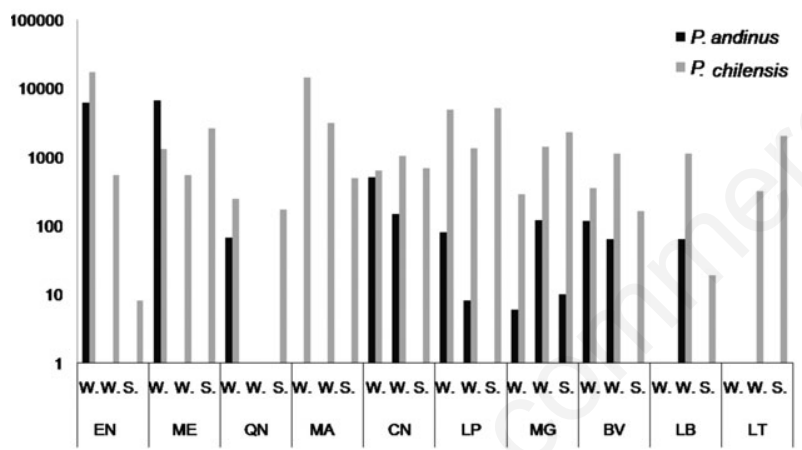

Fig. 2. Flamingoes density in W.W.S., i.e. winter 2009, winter 2010, summer 2010, in the lakes (logarithmic scale). larities (Mantel test) of the three sampling periods, winter 2009-winter $2010(\mathrm{r}=0.32, \mathrm{P}=0.21)$, winter 2009-summer $2010(\mathrm{r}=0.26, \mathrm{P}=0.84)$, and winter 2010-summer 2010 $(\mathrm{r}=0.045, \mathrm{P}=0.40)$, thus indicating that composition and abundance differences between samplings were important.

The seasonal changes in composition of the community were more evident for crustaceans. In summer time, Moina wierzejskii Richard, M. macrocopa (Straus), M. micrura and Daphnia spinulata Birabén were registered, while in winter time they were replaced by $D$. menucoensis Paggi and M. eugeniae Olivier. On the other hand, rotifers practically did not show so apparent seasonal differences.

In winter 2009, the dominant species were Brachionus dimidiatus, Daphnia menucoensis and Boeckella popooensis. In winter 2010, the dominant ones were Brachionus angularis, $B$. dimidiatus, $B$. pterodinoides Rousselet, Boeckella poopoensis, and Harpacticoida. In summer 2010, the dominant species were again B. angularis, B. dimidiatus in some lakes, but in others Filinia sp., Moina macrocopa, M. micrura, Daphnia spinulata and Metacyclops mendocinus were the prevailing ones.

The total number of species in each lake, alpha diversity, varied in a range of 0 to 12 . The mean alpha diversity was lower in winter [3.29 (0.86)], than in summer [7.77 $(0.29)$, with $\mathrm{t}=3.98$ and $\mathrm{P}=0.007$. The gamma diversity varied seasonally, being of 5 and 6 species in winters 2009 and 2010, and 12 in summer 2010.

The beta diversities were 7.40 and 5.55 in winters 2009 and 2010, and 5.55 in summer 2010, so that the lakes were relatively homogeneous in composition whithin each season. However, taking into account the abundance of the species, the similarity varied notably among seasons, as evidenced by the changes in cluster groups (Fig. 3).

The mean Shannon diversity index of each lake ranged between 1.21 and 1.26.

Tab. 2. Classification of the lakes according to Hammer (1986).

\begin{tabular}{|c|c|c|c|c|c|c|}
\hline \multirow[t]{2}{*}{ Lake } & \multicolumn{2}{|c|}{ Winter 2009} & \multicolumn{2}{|c|}{ Winter 2010} & \multicolumn{2}{|c|}{ Summer 2010} \\
\hline & $\begin{array}{c}\text { Salinity } \\
\left(\mathrm{g} \mathrm{L}^{-1}\right)\end{array}$ & Category & $\begin{array}{c}\text { Salinity } \\
\left(\mathrm{g} \mathrm{L}^{-1}\right)\end{array}$ & Category & $\begin{array}{l}\text { Salinity } \\
\left(\mathrm{g} \mathrm{L}^{-1}\right)\end{array}$ & Category \\
\hline$\overline{\mathrm{EN}}$ & 6 & Hiposaline & 1.88 & Subsaline & 1 & Subsaline \\
\hline $\mathrm{ME}$ & 7 & Hiposaline & 3.6 & Hiposaline & 2 & Subsaline \\
\hline QN & 6 & Hiposaline & 4.04 & Hiposaline & & Subsaline \\
\hline MA & 18 & Hiposaline & 4.84 & Hiposaline & 3 & Subsaline \\
\hline $\mathrm{CN}$ & 20 & Mesosaline & 12.26 & Hiposaline & 4 & Hiposaline \\
\hline LP & 15.5 & Hiposaline & * & $*$ & 9 & Hiposaline \\
\hline MG & 23 & Mesosaline & 7.72 & Hiposaline & 5 & Hiposaline \\
\hline BV & 22 & Mesosaline & 15.4 & Hiposaline & 8 & Hiposaline \\
\hline LB & 42 & Mesosaline & 6.41 & Hiposaline & 5 & Hiposaline \\
\hline LT & 132 & Hypersaline & 46.3 & Mesosaline & 8 & Hiposaline \\
\hline
\end{tabular}

EN, Las Encadenadas; ME, Melincué; QN, Quirno; MA, Maggiolo; CN, Carmen; LP, La Picasa; MG, Martín García; BV, Bella Vista; LB, La Badenia, LT, Las Tunas.

"No data. 


\section{Abundance}

A comprehensive analysis including all dates and lakes showed that there was a group of lakes (QN+ MA $+\mathrm{LP}+\mathrm{CN}+\mathrm{LT})$ with mean zooplankton abundances higher than 900 ind $\mathrm{L}^{-1}$ and another group $(\mathrm{EN}+\mathrm{ME}+\mathrm{LB})$ with values as low as 200 ind $\mathrm{L}^{-1}$. The mean abundance varied seasonally: 1187 ind $\mathrm{L}^{-1}$ [coefficient of variation $(\mathrm{CV})=138 \mathrm{~d}$ and 755 ind $\mathrm{L}^{-1}(\mathrm{CV}=84)$ in winters 2009 and 2010, and 3285 ind $\mathrm{L}^{-1}(\mathrm{CV}=173)$ in summer 2010 .

The general zooplankton abundance ranged from a minimum of 0 ind $\mathrm{L}^{-1}$ in winter 2009 at LT, LB, BV, to a maximum of 16,344 ind $\mathrm{L}^{-1}$ in summer 2010 at LP.

Crustaceans (cladocerans and copepods) represented more than $70 \%$ of the zooplankton density in 8 of the studied lakes but they represented less than 50\% in BV and ME (Tab. 4).

\section{Size and biomass}

The analysis of the total data of mean zooplankton size allows to determine the existence of two groups of lakes, one with body size smaller than $500 \mu \mathrm{m}(\mathrm{EN}, \mathrm{ME}, \mathrm{QN}$, MA, CN) and another with a size over than $500 \mu \mathrm{m}$ (LP, $\mathrm{MG}, \mathrm{BV}, \mathrm{LB}, \mathrm{LT})$. In winter and summer 2010, the mean size was $544(\mathrm{CV}=84)$ and $536 \mu \mathrm{m}(\mathrm{CV}=80)$, respectively. The mean size was lower and more homogeneous in winter 2009, being $360 \mu \mathrm{m}(\mathrm{CV}=50)$. The lowest and highest mean size was $348 \mu \mathrm{m}$ at QN and $670 \mu \mathrm{m}$ at LB, respectively (Fig. 4).

The mean biomass was $678(\mathrm{CV}=98)$ and $9981 \mu \mathrm{g} \mathrm{L}^{-1}$, $(\mathrm{CV}=106)$ in winters 2009 and 2010, and $3176 \mu \mathrm{g} \mathrm{L}^{-1}$ $(C V=224)$ in the summer of 2010. The values of zooplankton biomass varied among lakes (Fig. 5).

An one-way analysis of variance, where all lakes were combined in each season, shows that there were significant differences in the mean size of the three periods $(\mathrm{F}=26.5, \mathrm{P}<0.0001)$ and a Tukey-Kramer multiple comparisons post-test showed that winter 2009 was significantly different from both summer and winter 2010 $(\mathrm{P}<0.001)$, while there were no differences between them $(\mathrm{P}>0.05)$.

We did not find any significant correlations between

Tab. 3. List of taxa recorded in the lakes.

\begin{tabular}{|c|c|c|c|c|c|c|c|c|c|c|}
\hline & EN & ME & QN & MA & $\mathrm{CN}$ & LP & MG & $\mathrm{BV}$ & LB & LT \\
\hline \multicolumn{11}{|l|}{ Rotifera } \\
\hline Brachionus angularis Gosse & & $\mathrm{x}$ & $\mathrm{x}$ & $\mathrm{x}$ & $\mathrm{x}$ & $\mathrm{x}$ & & $\mathrm{x}$ & & $\mathrm{x}$ \\
\hline Brachionus calyciflorus Pallas & $\mathrm{x}$ & & & & $\mathrm{x}$ & & & & & $\mathrm{x}$ \\
\hline Brachionus caudatus Barrois and Daday & $\mathrm{x}$ & & & & & & & & & \\
\hline Brachionus dimidiatus Bryce & $\mathrm{x}$ & & $\mathrm{x}$ & $\mathrm{x}$ & $\mathrm{x}$ & $\mathrm{x}$ & & $\mathrm{x}$ & $\mathrm{x}$ & \\
\hline Brachionus plicatilis Müller & $\mathrm{x}$ & $\mathrm{x}$ & $\mathrm{x}$ & $\mathrm{x}$ & $\mathrm{x}$ & $\mathrm{x}$ & $\mathrm{x}$ & & & $\mathrm{x}$ \\
\hline Brachionus plicatilis s.l. Müller & & & & $\mathrm{x}$ & & & & & & $\mathrm{x}$ \\
\hline Brachionus pterodinoides Rousselet & & & $\mathrm{x}$ & & & & & & & \\
\hline Filinia sp. & & $\mathrm{x}$ & & & & & & & & \\
\hline Hexartha fennica (Levander) & & & & & & & & & & $\mathrm{x}$ \\
\hline Lecane luna (Müller) & & & & & & & & & $\mathrm{x}$ & \\
\hline Polyarthra sp. & & & $\mathrm{x}$ & & & & & & & $\mathrm{x}$ \\
\hline Pompholix sp. & $\mathrm{x}$ & & & & & & & & $\mathrm{x}$ & \\
\hline \multicolumn{11}{|l|}{ Copepoda } \\
\hline Boeckella poopoensis Marsh & $\mathrm{x}$ & $\mathrm{x}$ & $\mathrm{x}$ & & $\mathrm{x}$ & $\mathrm{x}$ & $\mathrm{x}$ & & & \\
\hline Boeckella gracilis (Daday) & & $\mathrm{x}$ & & $\mathrm{x}$ & & & & & $\mathrm{x}$ & \\
\hline Metacyclops mendocinus (Wierzejski) & $\mathrm{x}$ & $\mathrm{x}$ & & $\mathrm{x}$ & $\mathrm{x}$ & $\mathrm{x}$ & $\mathrm{x}$ & $\mathrm{x}$ & $\mathrm{x}$ & $\mathrm{x}$ \\
\hline Harpacticoida & & $\mathrm{x}$ & $\mathrm{x}$ & $\mathrm{x}$ & $\mathrm{x}$ & & $\mathrm{x}$ & & & $\mathrm{x}$ \\
\hline \multicolumn{11}{|l|}{ Cladocera } \\
\hline Alona sp. & & & $\mathrm{x}$ & & & & & & & \\
\hline Coronatella aff. rectangula (Sars) & & & & & & & & & $\mathrm{x}$ & \\
\hline Daphnia menucoensis Paggi & & $\mathrm{x}$ & $\mathrm{x}$ & $\mathrm{x}$ & & & & & & \\
\hline Daphnia spinulata Birabén & $\mathrm{x}$ & & & & & & & & $\mathrm{x}$ & \\
\hline Diaphanosoma birgei Korinek & & & & $\mathrm{x}$ & & & & & $\mathrm{x}$ & \\
\hline Leydigia acanthocercoides s.l. Fisher & & & $\mathrm{x}$ & & & & $\mathrm{x}$ & & & \\
\hline Moina eugeniae Olivier & & $\mathrm{x}$ & & & & & & $\mathrm{x}$ & & \\
\hline Moina macrocopa (Straus) & $\mathrm{x}$ & & & & & & & & & \\
\hline Moina micrura Kurz & $\mathrm{x}$ & $\mathrm{x}$ & $\mathrm{x}$ & & $\mathrm{x}$ & & $\mathrm{x}$ & & $\mathrm{x}$ & $\mathrm{x}$ \\
\hline Moina wierzejskii Richard & & & & $\mathrm{x}$ & & & & & $\mathrm{x}$ & \\
\hline Macrothrix sp. & & & & & $\mathrm{x}$ & & & & $\mathrm{x}$ & \\
\hline Ostracoda & $\mathrm{x}$ & $\mathrm{x}$ & $\mathrm{x}$ & $\mathrm{x}$ & $\mathrm{x}$ & & $\mathrm{x}$ & & $\mathrm{x}$ & \\
\hline
\end{tabular}

EN, Las Encadenadas; ME, Melincué; QN, Quirno; MA, Maggiolo; CN, Carmen; LP, La Picasa; MG, Martín Garcí; BV, Bella Vista; LB, La Badenia; LT, Las Tunas. 

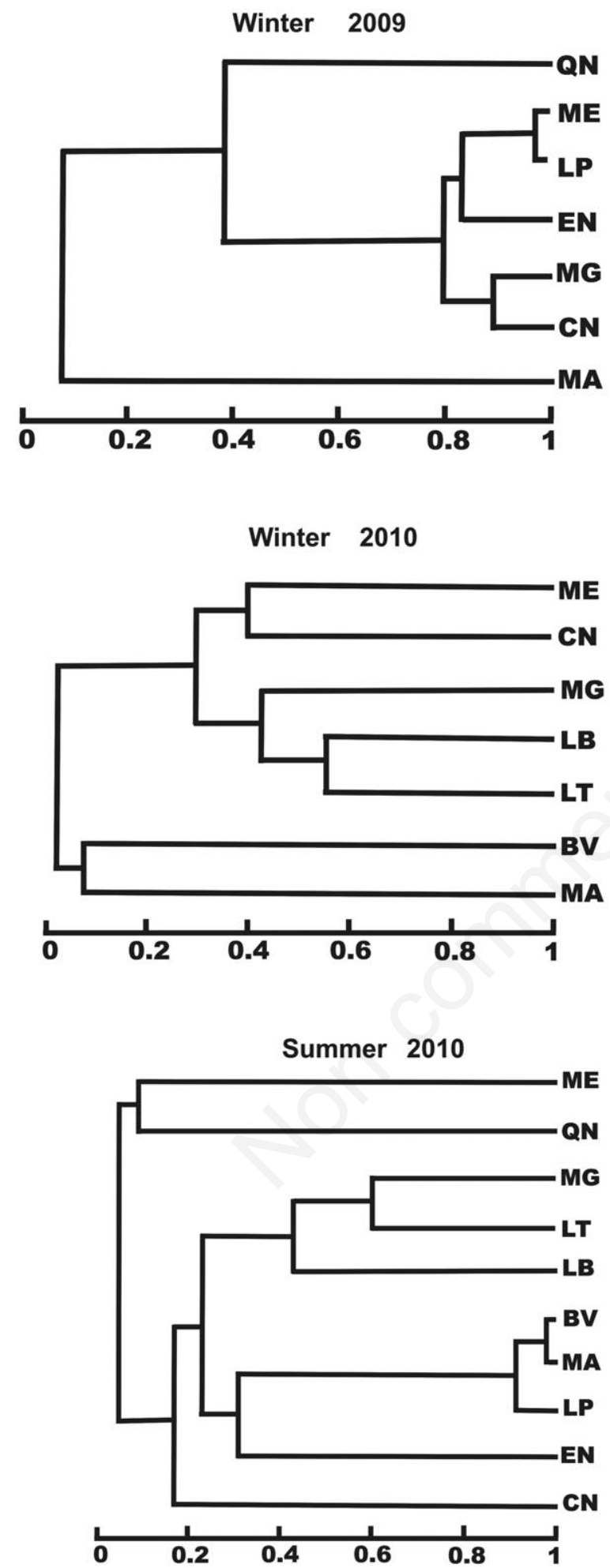

Fig. 3. Faunistic similarity among lakes. QN=Quirno; $\mathrm{ME}=$ Melincué; $\mathrm{LP}=\mathrm{La}$ Picasa; $\mathrm{EN}=$ Las Encadenadas; $\mathrm{MG}=$ Martín García; $\mathrm{CN}=$ Carmen; MA=Maggiolo; $\mathrm{LB}=\mathrm{La}$ Badenia; LT=Las Tunas; BV=Bella Vista. total zooplankton abundance or biomass and conductivity, for all the seasons in all lakes. However, the relation between mean salinity and biomass for season was significant ( $\mathrm{r}=0.8258, \mathrm{P}=0.0032)$.

A negative correlation between zooplankton mean size and abundance of $P$. chilensis was found $(\mathrm{r}=-0.4702$, $\mathrm{P}=0.020$ ). The relationship between zooplankton mean size and $P$. andinus abundance was not significant $(\mathrm{r}=-0.219$, $\mathrm{P}=0.451)$.

\section{DISCUSSION}

\section{Zooplankton features}

The composition of the lakes zooplankton included a high number of cosmopolitan species in rotifer and a pratically total dominance of Neotropical species in copepoods and cladocerans of which we can mention Boeckella poopoensis, B. gracilis Daday, Daphnia menucoensis and Moina eugeniae as the most noticeable examples.
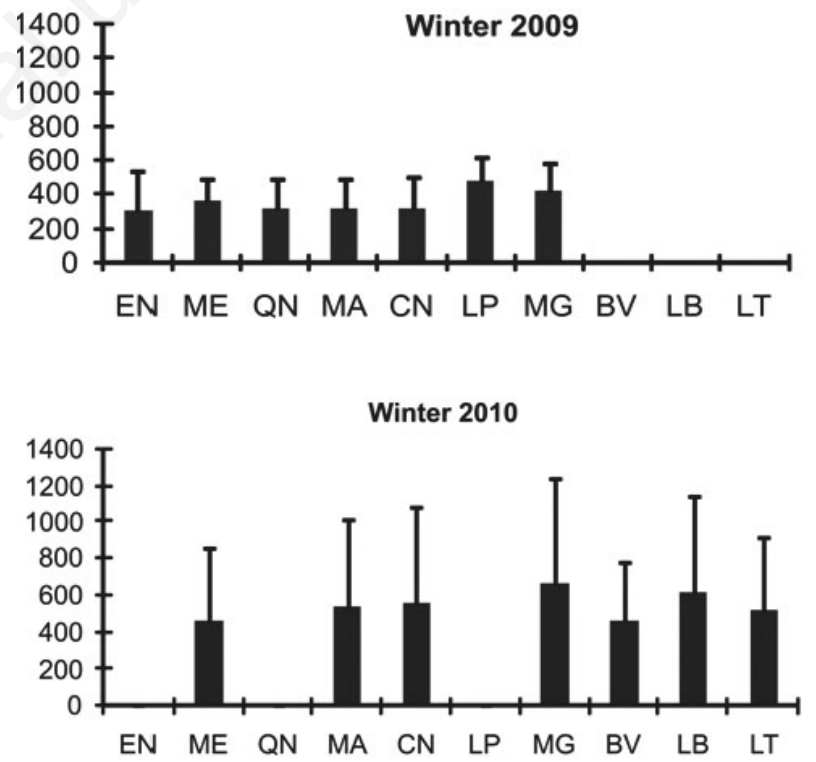

Summer 2010

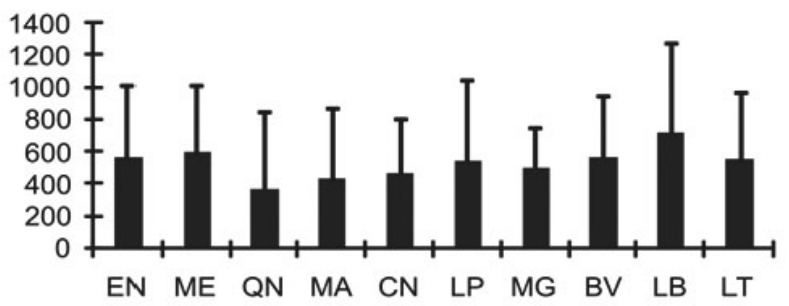

Fig. 4. Mean zooplankton size $(\mu \mathrm{m})$. Whiskers indicate standard deviation values. EN=Las Encadenadas; $\mathrm{ME}=$ Melincué; $\mathrm{QN}=$ Quirno; MA=Maggiolo; $\mathrm{CN}=$ Carmen; $\mathrm{LP}=$ La Picasa; $\mathrm{MG}=$ Martín García; BV=Bella Vista; LB=La Badenia; LT=Las Tunas. 
The zooplankton included several species of rotifers, which were good indicators of the salinity level of waters, such as Brachionus angularis, $B$. dimidiatus, B. plicatilis (Fontaneto et al., 2006). Several of the dominant microcrustaceans can also be considered as indicators of high levels of salinity, i.e. Moina eugeniae, D. menucoensis and B. poopoensis (Paggi, 1998; Echaniz et al., 2006).

Salinity is generally considered as a fundamental ecological parameter and shaping force of the communities features. The analysis of the species association patterns (Fig. 2) suggests the existence of a gradient with well-defined assemblages at the extremes. These assemblages are composed of representative species related to the levels of water salinity and also to some extent to the chemical nature of water.

Taking into account the chemical composition of waters, it was observed that in those lakes with higher levels of sulphate (LB, LT), copepods and cladocerans were dominant when salinity was lower (winter and summer of 2010).

In the $\mathrm{MG}$ lake with high levels of $\mathrm{Mg}$ and $\mathrm{Ca}$, the most abundant zooplankters were copepods, though Moina eugeniae cladoceran was also very abundant. In North American lakes with similar chemical features, Bos et al. (1996) reported the abundant presence of $M$. hutchinsoni (Brem), a species close to M. eugeniae. In lakes with high concentrations of chloride (BV, QN and $\mathrm{CN}), B$. angularis, $B$. dimidiatus and an unidentified harpacticoid copepod were very abundant. Derry et al. (2003) found that in Canadian shallow lakes with chloride waters, B. plicatilis and the hapacticoid copepod Cletocampus sp., were the dominant species. However, it cannot be claimed that some abundant species such as Moina micrura and Metacyclops mendocinus should be considered indicators of a narrow range of salinity or a limited ionic concentration because they generally show a relatively wide range of tolerance (Rzóska, 1961; Alonso, 1996; Sterza and Fernández, 2006; Santangelo et al., 2008; Brucet et al., 2009).

The low richness and high biomass of zooplankton recorded in this study is a common feature of saline lakes (Hurlbert and Chang, 1983; Green, 1993; Evans et al., 1996; Williams, 1998) including those already studied in Argentina (Echaniz et al., 2006; Echaniz, 2010).

The lakes under study, even when their zooplankton was sampled in only three opportunities, showed a remarkably low richness as compared with other geographically neighbouring shallow lakes belonging to the Parana

Tab. 4. Total and mean abundance of Rotifera, Cladocera and Copepoda in the lakes.

\begin{tabular}{lccccccccccc}
\hline & & EN & ME & QN & MA & CN & LP & MG & BV & LB & LT \\
\hline Rotifera (ind L ${ }^{-1}$ ) & W 09 & 19.20 & 0.00 & 88.88 & 1177.78 & 250.00 & 0.00 & 0.00 & 0.00 & 0.00 & 0.00 \\
& W 10 & $*$ & 4.44 & $*$ & 220.00 & 3.33 & $*$ & 58.33 & 896.67 & 16.67 & 150.00 \\
& S 10 & 61.83 & 131.83 & 204.17 & 61.83 & 171.50 & 4608.33 & 0.00 & 0.00 & 19.83 & 557.67 \\
& Mean & 27.01 & 45.42 & 97.68 & 486.54 & 141.61 & 1536.11 & 19.44 & 298.89 & 12.17 & 235.89 \\
& (CV) & $(32)$ & $(75)$ & $(102)$ & $(604)$ & $(126)$ & $(2661)$ & $(34)$ & $(518)$ & $(11)$ & $(289)$ \\
\hline Cladocera (ind L-1) & W 09 & 0.00 & 20.00 & 1355.55 & 466.66 & 0.00 & 0.00 & 0.00 & 0.00 & 0.00 & 0.00 \\
& W 10 & $*$ & 2.22 & $*$ & 6.67 & 20.00 & $*$ & 0.00 & 3.33 & 30.00 & 0.00 \\
& S 10 & 110.83 & 22.17 & 1597.17 & 0.00 & 17.50 & 0.00 & 72.72 & 3.50 & 81.67 & 1446.67 \\
& Mean & 36.94 & 14.80 & 984.24 & 157.78 & 12.50 & 0.00 & 24.24 & 2.28 & 37.22 & 482.22 \\
& (CV) & $(64)$ & $(11)$ & $(861)$ & $(268)$ & $(11)$ & & $(42)$ & $(2)$ & $(41)$ & $(835)$ \\
\hline Copepoda (ind L-1) & W 09 & 57.60 & 155.54 & 108.88 & 0.00 & 4850.00 & 719.33 & 1622.22 & 0.00 & 0.00 & 0.00 \\
& W 10 & $*$ & 36.67 & $*$ & 66.67 & 886.67 & $*$ & 60.00 & 80.00 & 373.33 & 406.67 \\
& S 10 & 66.50 & 79.33 & 8.17 & 719.83 & 225.17 & $11,735.50$ & 68.44 & 105.00 & 16.33 & 1655.67 \\
& Mean & 41.37 & 90.51 & 39.02 & 262.17 & 1987.28 & 4151.61 & 583.55 & 61.67 & 129.89 & 687.45 \\
& (CV) & $(36)$ & $(60)$ & $(61)$ & $(378)$ & $(2501)$ & $(6578)$ & $(899)$ & $(55)$ & $(211)$ & $(863)$ \\
\hline Total zooplankton (ind L-1) & W 09 & 76.8 & 175.54 & 1553.31 & 1644.44 & 5100 & 719.33 & 1622.22 & 0.00 & 0.00 & 0.00 \\
& W 10 & $*$ & 43.33 & $*$ & 293.34 & 910 & $*$ & 118.33 & 980 & 420 & 556.67 \\
& S 10 & 239.16 & 233.33 & 1809.51 & 781.66 & 414.17 & $16,343.83$ & 141.16 & 108.5 & 117.83 & 3660.01 \\
& Mean & 157.98 & 150.73 & 1681.41 & 906.48 & 2141.39 & 8531.58 & 627.24 & 362.83 & 179.28 & 1405.56 \\
& (CV) & $(73)$ & $(65)$ & $(11)$ & $(75)$ & $(120)$ & $(129)$ & $(137)$ & $(148)$ & $(121)$ & $(140)$ \\
\hline
\end{tabular}

EN, Las Encadenadas; ME, Melincué; QN, Quirno; MA, Maggiolo; CN, Carmen; LP, La Picasa; MG, Martín Garcia; BV, Bella Vista; LB, La Badenia; LT, Las Tunas; W 09, winter 2009; W 10, winter 2010; S 10, summer 2010; CV, coefficient of variation.

"No data. 
river basin (José de Paggi and Paggi, 2007). The highest richness was recorded at LB, with only 12 species. At lower salinity, in general, rotifers are the dominant organisms, in contrast with the enviroments with high salinity where dominance is transferred to microcrustaceans. A similar relationship was found by Echaniz (2010), in other lowland saline environments of Argentina.

The richness of the zooplankton communities of inland waters greatly depends on salinity along with tem-

\section{Winter 2009}
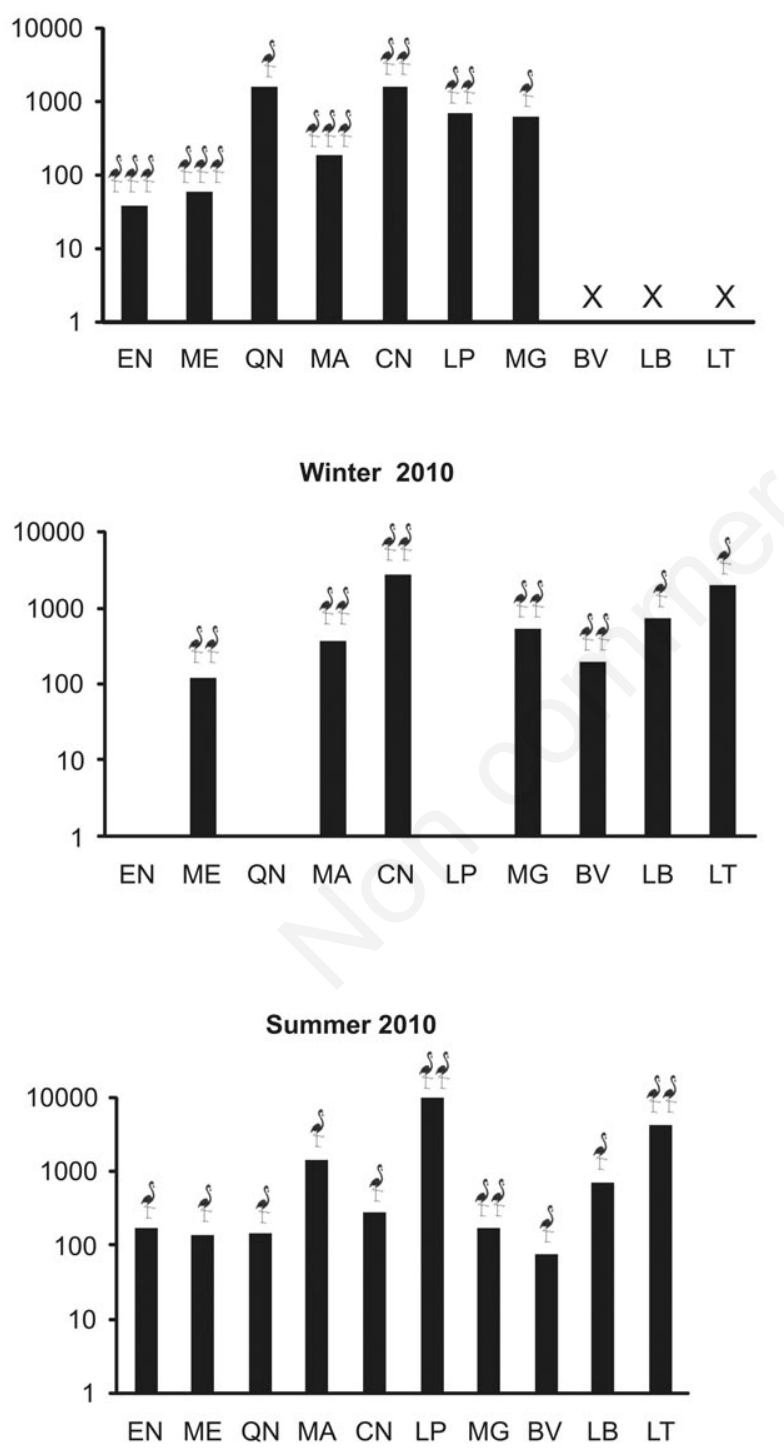

Fig. 5. Zooplankton biomass ( $\mu \mathrm{g} \mathrm{L}^{-1}$, logarithmic scale). The size of the flamingoes population is indicated by the number of flamingoes (i.e. 1 flamingo $=<1000$ individuals, 2 flamingoes $=1000$ to 7000 individuals, and 3 flamingoes $>7000$ individuals). perature, as driving factors whose effects would be exerted in opposite ways (Kaya et al., 2010). In the lakes studied here, the positive effect of temperature on the richness of zooplankton seems to be counteracted by the constraining effect of salinity.

The analysis of the available information as a whole, without discriminating lakes or seasons, indicates a lack of a statistical correlation between salinity and biomass. However, if the same analysis is based upon the mean values of these two parameters of each of the ten lakes studied, the relationship between them is significant.

Nonetheless, it shoud be pointed out that in winter 2009 , in the lakes of higher salinity (BV, LT, LB) - with maximum and mean values of 132 and $65 \mathrm{~g} \mathrm{~L}^{-1}$ which probably are as high or higher than their tolerance limits no zooplanktonic organisms were registered. At that time, these lakes had a very small volume of water and were in an apparent drying process. Presumably, the species living there had already received environmental signals triggering the biological mechanisms producing dormant stages.

\section{Flamingoes and zooplankton}

According to Hurlbert et al. (1986), the presence of flamingoes is indicative of the alimentary conditions and density of preys. Despite some differences found between the lakes studied, they have an abundant zooplankton with a relatively homogeneous composition, as shown by their low beta diversity.

Since Hrbáček et al. (1961) and Brooks and Dodson (1965), it is widely accepted that fish predation plays a key role in determining the zooplankton size structure of inland waters. However, the presence of fishes was scarcely detected only in few lakes (M. Romano, personal observation). Most of the lakes studied, due to their instability and high salinity, are not favourable environments for the development of permanent and abundant populations of fish, even for those halotolerant species common in the region, such as Odontesthes bonariensis (Valenciennes) and Jenynsia multidentata (Jenyns). Salinity and changes of this abiotic factor seem to be some of the main reasons for the absence of fishes in Pampean lakes (Menni et al., 1988; Gómez, 1996; Gómez et al., 2007). In the Andes of Southern Peru (3700-4700 m asl), Sick (2001) and Hurlbert et al. (1986) found that Chilean flamingoes are usually absent or scarce in lakes with fish and present in large numbers where fish are absent. The dominance of microcrustaceans in lakes agrees with the absence or low density of fish.

There is a negative correlation between the mean size of zooplankton and the abundance of the flamingo $P$. chilensis which can be interpreted as a result of an active zooplanktophagous behaviour biassed to feeding upon the larger members of the community. Indeed this negative correlation is higher when it is separately calculated be- 
tween the abundance of $P$. chilensis and of macrozooplankton composed by adult crustaceans plus copepodit of copepods. Even though the main feeding source of this flamingo species would be algae, it is quite probable that it may occasionally also use some smaller members of the zooplankton as food.

Hence, the differences observed in the mean body size of the zooplankton could be reasonably related to the presence of flamingoes, specifically P. chilensis, which could selectively impact on the largest members of this community. Therefore, during winter 2009, when the abundance of this species of flamingoes was about three times higher than in the other two sampling periods the mean size of zooplankton was lower. The correlation coefficient between mean size of zooplankton and abundance of flamingoes supports the above discussion which suggests a negative relationship. In summer, this effect was not so clearly observed regarding biomass probably because of the effect of a higher abundance, higher rate of reproduction and fertility of zooplankton, during this season supported by a high primary production. In this season, phytoplankton reached very high densities with a mean of 43,730 cel mL $\mathrm{m}^{-1}$ and maximum of $342,592 \mathrm{cel} \mathrm{mL} \mathrm{m}^{-1}$ in LP (W. Polla, personal communication). Consequently, it is probable that at that time the food avalilability for zooplankton was so high that the impact of the flamingoes feeding upon zooplankton was not easy to discern.

The high abundance of zooplankton with strong dominances and the very low Shannon index values $<1.5$, indicate eutrophy in most lakes (Margalef, 1983). Due to the dominance of relatively large zooplankton like calanoid copepods and Daphnia, the biomass of the lakes zooplankton was high, indicating a good potential food source. It is remarkable that in those lakes where no zooplankton was found (LB, LT, QN), flamingoes were not present or were found as rather small populations $[<500$ specimens].

\section{CONCLUSIONS}

Taking into account that lowland lakes in Argentina are key habitats for vulnerable species of flamingoes all the year round (Bucher and Curto, 2012) or especially during winter when some of the high-Andes lakes in Argentina, Bolivia, Chile and Perú freeze (Caziani et al., 2007), further research on zooplankton is needed. They would be a tool for monitoring the ecological quality of the wetlands related to the conservation biology of flamingoes, particularly for $P$. chilensis, the most abundant species, wich can use zooplankters as a food source.

On the other hand, the need for protection of the salt lakes as habitats and food sources for waterfowl, and as important reservoirs of biodiversity has been claimed in different parts of the world (Horváth et al., 2012, 2013). Water bodies of Pampa de las Lagunas are threatened by many anthropic activities, resulting from land use, agriculture, livestock, with the subsequent deposition of a significant amount of organic wastes, fertilisers and pesticides (Miglioranza et al., 2003; Romano et al., 2005; Pengue, 2005; Peruzzo et al., 2008) The high concentrations of $\mathrm{P}$ and phytoplankton registered are indicative of eutrophic aquatic environments. Moreover, the high productivity of this kind of lakes would be closely related to a sort of close cycle flamingoes-algae-sediments and the higher solubility of phosphorous compounds under extreme conditions of alkalinity (Moss, 1998). In order to protect and maintain the environmental integrity of these lakes, it is necessary to have a better insight into their limnological functioning as a basis for a future conservation policy.

\section{ACKNOWLEDGMENTS}

The study was carried out in the framework of the projects Design and Implementation of a Network of Wetlands of Importance for Flamingo Conservation and Diversity of rotifers and crustaceans of Parana river basin (CAI+D 2009, Universidad Nacional del Litoral). The authors wish to thank Wanda Polla for her valuable help with the field work and the collaboration of Federico Philpott and his family (Estancia El Amanecer), Eduardo Weichhart (Estancia Santa Marta), and Santos and Cristian Sánchez (Estancia San Carlos). Thanks are also given to Secretaria de Medio Ambiente de la Provincia de Santa $\mathrm{Fe}$, for the chemical analysis. We thank the editor and two anonymous reviewers for their constructive comments.

\section{REFERENCES}

Ahlstrom EH, 1940. A revision of the Rotatorian genera Brachionus and Platyias with descriptions of one new species and two new varieties. B. Am. Mus. Nat. Hist. 77:143-148.

Alekseev VR, 2002. Copepoda, p. 123-188. In: C.H. Fernando (ed.), A guide to tropical freshwater zooplankton. Backhugs Publ.

Alonso M, 1996. [Crustacea, Branchiopoda], p. 1-486. In: M.A. Ramos et al. (eds.), [Fauna Ibérica]. [Book in Spanish]. Museo Nacional de Ciencias Naturales ed.

APHA, 1989. Standard methods for the examination of water and wastewater, $17^{\text {th }}$ ed. American Public Health Association ed., New York: 1460 pp.

Bayly IA, 1992. The non-marine Centropagidae (Copepoda: Calanoida) of the world, p. 1-30. In: H.J. Dumont (ed.), Guides to the identification of the microinvertebrates of the continental waters of the world. SPB Academic Publ.

BirdLife International, 2008a. Phoenicoparrus andinus. IUCN red list of threatened species. Version 2011.2. Available from: http://www.iucnredlist.org/details/106003772/0

BirdLife International, 2008b. Phoenicopterus chilensis. IUCN red list of threatened species. Version 2011.2. Available from: http:/www.iucnredlist.org/details/106003770/0

Bos D, Cumming B, Watters C, Smol J, 1996. The relationship between zooplankton, conductivity and lake-water ionic composition in 111 lakes from the Interior Plateau of British Columbia, Canada. Int. J. Salt Lake Res. 5:1-15. 
Brooks JL, Dodson SI, 1965. Predation, body size and the composition of plankton. Science 150:28-35.

Brucet S, Boix D, Gascón S, Sala J, Quintana XD, Badosa A, Søndergaard M, Lauridsen CTL, Jeppesen E, 2009. Species richness of crustacean zooplankton and trophic structure of brackish lagoons in contrasting climate zones: north temperate. Denmark and Mediterranean Catalonia (Spain). Ecography 32:692-702.

Bucher EH, Curto E, 2012. Influence of long-term climatic changes on breeding of the Chilean flamingo in Mar Chiquita, Córdoba, Argentina. Hydrobiologia 697:127-137.

Caziani SM, Rocha O, Rodriguez E, Romano M, Derlindati EJ, Talamo A, Ricalde D, Quiroga C, Contreras JP, Valqui M, Sosa H, 2007. Seasonal distribution, abundance, and nesting of Puna, Andean, and Chilean flamingos. Condor 109:276287.

Ciros-Perez J, Gomez A, Serra M, 2001. On the taxonomy of three sympatric sibling species of the Brachionus plicatilis (Rotifera) complex from Spain, with the description of $B$. ibericus n.sp. J. Plankton Res. 23:1311-1328.

Del Hoyo J, 1992. Phoenicopteridae (Flamingos), p. 508-526. In: J. Del Hoyo, A. Elliott, and J. Sargatal (eds.), Handbook of the birds of the world. Lynx ed.

Derry A, Prepas E, Hebert P, 2003. A comparison of zooplankton communities in saline lake water with variable anion composition. Hydrobiologia 505:199-215.

Dumont HJ, Van de Velde I, Dumont S, 1975. The dry weight estimate of biomass in a selection of Cladocera, Copepoda, and Rotifera from the plankton, periphyton and benthos of continental waters. Oecologia 19:75-97.

Echaniz S, 2010. [Composición y abundancia del zooplancton en lagunas de diferente composición iónica de la Provincia de la Pampa]. [PhD Thesis in Spanish]. Universidad Nacional de Rio Cuarto ed., Rio Cuarto:169 pp.

Echaniz S, Vignatti A, José de Paggi A, Paggi J, Pilati A, 2006. Zooplankton seasonal abundance of South American saline shallow lakes. Int. Rev. Hydrobiol. 91:86-100.

Evans M, Arts M, Robarts R, 1996. Algal productivity, algal biomass, and zooplankton biomass in a phosphorus-rich saline lake: deviations from regression model predictions. Can. J. Fish. Aquat. Sci. 53:1048-1060.

Fontaneto D, De Smet WH, Ricci R, 2006. Rotifers in saltwater environments, re-evaluation of an inconspicuous taxon. J. Mar Biol. Assoc. UK 86:623-656.

Gómez SE, 1996. [Resistenza alla temperatura e salinità in pesci della provincia di Buenos Aires (Argentina), con implicazioni zoogeografiche], p. 171-192. In: Proc. $4^{\text {th }}$ National Congress Freswhater Italian Assoc. [Proc. in Italian]. Freswhater Italian Assoc. ed.

Gómez SE, Menni RC, Gonzalez Naya J, Ramirez L, 2007. The physical-chemical habitat of the Buenos Aires pejerrey, Odontesthes bonariensis (Teleostei, Atherinopsidae), with a proposal of a water quality index. Environ. Biol. Fish. 78:161-171.

Green J, 1993. Zooplankton associations in East African Lakes spanning a wide salinity range. Hydrobiologia 267:249-256.

Hammer Ø, Harper DAT, Ryan PD, 2001. PAST: paleontological statistics software package for education and data analysis. Palaeontologia. Available from: http://palaeo-electronica. org/2001_1/past/past.pdf
Hammer UT, 1986. Saline lake ecosystems of the world. Dr. W. Junk Publ., Dordrecht: 616 pp.

Harrison S, Ross SJ, Lawton JH, 1992. Beta diversity on geographic gradients in Britain. Ecology 61:151-158.

Horváth Z, Ferenczi M, Móra A, Vad CF, Ambrus A, Forró L, Szövényi G, Andrikovics S, 2012. Invertebrate food sources for waterbirds provided by the reconstructed wetland of Nyirkai-Hany, northwestern Hungary. Hydrobiologia 697:59-72.

Horváth Z, Vad CF, Vörös L, Boros E, 2013. Distribution and conservation status of fairy shrimps (Crustacea: Anostraca) in the astatic soda pans of the Carpathian basin: the role of local and spatial factors. J. Limnol. 72:e9.

Hrbáček J, Dvořáková M, Kořínek V, Procházková L, 1961. Demonstration of the effect of fish stock on the species composition of zooplankton and the intensity of metabolism of the whole plankton association. Int. Verh. Theor. Angew. 14:192-195.

Hurlbert SH, 1982. Limnological studies of flamingo diets and distributions. Natl. Geogr. Res. 14:35 1-356.

Hurlbert SH, Chang C, 1983. Ornitholimnology: effects of grazing by the andean flamingo (Phoenicoparrus andinus). P. Natl. Acad. Sci. USA 80:4766-4769.

Hurlbert SH, Loayza W, Moreno T, 1986. Fish-flamingo-plankton interactions in the Peruvian Andes. Limnol. Oceanogr. 31:457-468.

Hurlbert SH, López M, Keith JO, 1984. Wilson's phalarope in the Central Andes and its interaction with the Chilean flamingo. Rev. Chil. Hist. Nat. 57:47-57.

Iriondo M, Kröhling D, 2007. Geomorphology and sedimentology of the upper basin of the Salado River (Southern Santa Fe and NW Buenos Aires provinces; Argentina). Lat. Am. J. Sedimentol. Basin Anal. 14:1-23.

Jenkin PM, 1957. The filter-feeding and food of flamingoes (Phoenicopteri). Philos. T. Roy. Soc. B 674:401-493.

José de Paggi S, Paggi JC, 2007. Zooplankton, p 229-245. In: M. Iriondo, J.C. Paggi, and J. Parma (eds.), The middle Parana river: limnology of a subtropical wetland. Springer.

Kaya M, Fontaneto D, Segers H, Altındağ A, 2010. Temperature and salinity as interacting drivers of species richness of planktonic rotifers in Turkish continental waters. J. Limnol. 69:297-304.

Kořínek V, 1981. Diaphanosoma birgei n. sp (Crustacea, Cladocera), a new species from America and it's widely distribution species Diaphanosoma birgei ssp. L acustris n ssp. Can. J. Zool. 59:1115-1121.

Kořínek V, 2002. Cladocera, p. 69-122. In: C.H. Fernando (ed.), A guide to tropical freshwater zooplankton. Backhuys Publ.

Korovchinski NM, 1992. Sididae and Holopedidae (Crustacea: Daphniiformes). Guides to identification of the microinvertebrates of the continental waters of the world. SPB Academic Publ., The Hage: 82 pp.

Koste W, 1978. [Rotatoria. Die Radertiere Mitteleuropas]. [Book in German]. Gebruder Borntraeger, Berlin: 673 pp.

Mantel N, Valand RS, 1970. A technique of nonparametric multivariate analysis. Biometrics 26:547-558.

Margalef R, 1983. [Limnología]. [Book in Spanish]. Omega ed., Barcelona: $1010 \mathrm{pp}$.

Mascitti V, Kravetz FO, 2002. Bill morphology of South American flamingos. Condor 104:73-83. 
Menni RC, López HL, Arámburu RH, 1988. [Ictiología de Sierra de la Ventana y Chasicó (Provincia de Buenos Aires, Argentina). Zoogeografía y parámetros ambientales]. [Article in Spanish]. An. Mus. Hist. Nat. Valparaiso 19:75-84.

Miglioranza K, Aizpón de Moreno J, Moreno V, 2003. Trends in soil science: organochlorine pesticides in Argentinean soils. J. Soil Sediment 4:264-265.

Morisita M, 1959. Measuring of interspecific association and similarity between communities. Mem. Fac. Sci. Kyushu Univ. Ser. E. Bio. 3:65-80.

Moss B, 1998. Ecology of fresh waters. Man and medium, past to future. Blackwell Science, Oxford: $572 \mathrm{pp}$.

Paggi J, 1998. [Cladócera (Anomopoda y Ctenopoda)], p. 507518. In: S. Coscaróna and J.J. Morrone (eds.), [Biodiversidad de Artrópodos Argentinos]. [Book in Spanish]. Sur ed.

Pengue W, 2005. Transgenic crops in Argentina: the ecological and social debt. B. Sci. Technol. Soc. 25:314-332.

Peruzzo P, Porta A, Ronco A, 2008. Levels of glyphosate in surface waters, sediments and soils associated with direct sowing soybean cultivation in north pampasic region of Argentina. Environ. Pollut. 156:61-66.

Romano M, Barberis IM, Derlindati EJ, Pagano F, Marconi P, Arengo F, 2009. Variation in abundance of Andean and Chilean Flamingos wintering in lowland wetlands of central Argenina in two contrasing years. Flamingo 17:11-16.
Romano M, Barberis IM, Pagano F, Maidagan J, 2005. Seasonal and interannual variation in waterbird abundance and species composition in the Melincue saline lake, Argentina. Eur. J. Wildlife Res. 51:1-13.

Romano M, Barberis IM, Pagano F, Marconi P, Arengo F, 2008. Winter monitoring of Andean and Chilean Flamingos in lowland wetlands of central Argentina. Flamingo 16:45-47.

Rzóska J, 1961. Observations on tropical rainpools and general remarks on the waters. Hydrobiologia 17:265-286.

Santangelo JM, Bozelli RL, Rocha AM, Esteves FA, 2008. Effects of slight salinity increases on Moina micrura (Cladocera) populations: field and laboratory observations. Mar. Freshwater Res. 59:808-816.

Sick H, 2001. [Ornitologia Brasileira]. [Book in Brasilian]. Nova Fronteira, Rio de Janeiro: $862 \mathrm{pp}$.

Sterza JM, Fernández L, 2006. Distribution and abundance of Cladocera (Branchiopoda) in the Paraíba do Sul River estuary, Rio de Janeiro, Brazil. Braz. J. Oceanogr. 54:193-204.

Weyl PK, 1964. On the changes in electrical conductance of the sea water with temperatura. Limnol. Oceanogr. 9:75-78.

Whittaker RH, 1972. Evolution and measurement of species diversity. Taxon 21:213-251.

Williams W, 1998. Salinity as a determinant of the structure of biological communities in salt lakes. Hydrobiologia 381:191-201. 